\title{
Title: A Multilevel Theory of Democratic Secession
}

\section{Rainer Bauböck}

Robert Schuman Centre for Advanced Studies, European University Institute, Florence, Italy

rainer.baubock@eui.eu

published in: Ethnopolitics, online first 8 March 2019. DOI: 10.1080/17449057.2019.1585088

Postprint version

Acknowledgements: I thank the anonymous reviewers and Jean-Thomas Arrighi and Dejan Stjepanovic, the editors of this special issue, as well as Joseph Lacey and David Owen for very helpful written comments and the participants at workshops in Neuchatel, Stockholm, Hamburg and at the EUI in Florence for oral feedback on early drafts of this paper.

Abstract: In this paper I sketch a relational approach that regards secession as the political upgrading of a self-governing territory within a multilevel constellation of polities. I consider territorial integrity, democratic diversity and recognition requirements as general constraints on secession from democratic polities. These principles support substantive and procedural conditions that vary, however, for local, sub-state regional and international secessions. Exit of a member state from a union is the only context in which secession is a unilateral right and even then it is constrained by a duty to negotiate fair terms of separation.

Keywords: secession, multilevel, constellation, polity, territorial integrity, diversity, recognition, citizenship, upgrading, realignment, exit 


\section{A Multilevel Theory of Secession}

\section{Introduction}

Secession, i.e. the voluntary withdrawal of a political territory from a larger one in which it was previously incorporated, is not a frequent phenomenon. This is not surprising. All polities have an interest in their territorial stability across time. What I mean by polities are ensembles of relatively autonomous government institutions exercising coercive power over a specific population and territory. Polities include independent states, autonomous territories at sub-state level, self-governing municipalities as well as supranational unions of states such as the European Union (EU). Democratic polities are those whose citizens freely elect their governments and hold them accountable. If the borders of political territories were not stable over time, democratic governments could not fulfil their most basic tasks of providing security to their citizens and resolving conflicts among them, let alone represent them in decisions that have long-term consequences. Moreover, frequent changes of borders would entangle governments in endless conflicts with those of neighbouring territories.

However, territorial borders do change occasionally. They did so quite frequently before the consolidation of the current international system when empires expanded through colonisation and territorial annexations or when rulers agreed to transfers of territory. They changed again when empires released their colonies into independence or when states broke up due to regime collapse or civil war. They can change also through voluntary (re)unification when neighbouring territories decide to merge into a larger one. In this paper, I will generally set aside all these scenarios and will be concerned only with secession, i.e. a voluntary breakaway of a polity from a territory of which it had previously been a part. 
Explanatory as well as normative secession theories are mostly level-specific because they apply only to independent states without considering secession at other levels. This is the case for the most advanced explanatory theory developed by Philip Roeder (2005). It is also the case for 'remedial-right-only' normative theories (Buchanan 1991, 1997, Buchanan 2004; Patten 2014; Stilz 2011, 2015) that have not tried to understand why within-state secessions and exit rights from regional unions are more often accepted than those from independent states. Liberal nationalist theories (Gans 1979; Miller, 1976; Moore, 2015; Nielsen, 1998; Philpott, 1995; Tamir 1993) aim to enhance the matching of national and political boundaries and might also apply to within-state secessions of linguistically and culturally distinct territories, such as the secession of Jura from canton Berne in the 1970s. They are also likely to defend unilateral secession rights from unions consisting of distinct nation-states, but have little to say about the redrawing of municipal borders. By contrast, associative-plebiscitarian theories (Beran 1984, 1989; Gauthier 1994; Pogge 1992; Steiner 1998; Wellman 1995, Wellman 2005) do not privilege any particular type of polity and are level-neutral - their criterion of legitimacy is always the same: democratic majority support in a secession referendum is sufficient provided the same right is granted to any territorial group that wants to break away from the post-secession territory. The empirical puzzle for all these theories is why in real-world democracies secession is handled so differently at different territorial levels.

This paper presents a normative secession theory that is neither level-neutral, nor levelspecific, but rather level-differentiated. The scope of analysis is limited to secession in stable democratic contexts. In section 2, I introduce a multilevel perspective that frames secession as a change of status or affiliation of a territory within a wider constellation of territorial polities. Section 3 defends a general democratic presumption against secession on grounds of territorial 
stability, democratic diversity and mutual recognition. Section 4 links different levels of permissiveness for secession to different citizenship regimes and democratic purposes of local, federated, independent and supra-state polities. Section 5 considers how substantive conditions

for legitimate secession vary across levels and section 6 does the same for procedural conditions of recognition. The conclusions summarise the innovative elements of the argument and point towards a hypothetical future in which territory may become less salient.

\section{Territorial Constellations and Status Changes}

Secession conceptually involves a candidate polity that aims to break away and a parent polity that it aims to break away from. Monolevel theories of secession consider only one type of parent polity as relevant: independent states. They frame secession as involving a claim for independent statehood raised by a candidate group and directed at the government of the state whose citizens and residents the members of the group currently are. The candidate group is variously thought of as an ascriptive (ethnic, linguistic, racial, religious) minority, as a stateless nation or as a group of dissenting citizens who want to live under a different government without having to emigrate. These theories assume that minorities, nations or dissenting groups must be territorially concentrated in order to effectively raise a claim to secession. Territory figures mostly as an instrumental resource control over which enables oppressed or dissatisfied groups to threaten with secession in order to either get central governments to meet their demands or to actually break apart the state. Alternatively, territory is also sometimes considered as the core object of rights claims raised by secessionists. The political nature of the territory that these candidate groups occupy prior to secession is, however, rarely relevant for monolevel theories. 
By contrast, in a multilevel perspective, secession is understood as a move to change the status or affiliation of a territory within a wider constellation of polities. What I mean by a constellation is an ensemble of distinct polities that are jointly involved in determining the political status of individuals or of a territory (Bauböck 2010). Complex constellations, such as federal states or the EU, do not only include horizontal relations (between territorial polities that enjoy equal legal status, as independent states or the provinces of a federation do) but also vertical relations between several levels of territorially nested polities. The present paper extends the constellations perspective, which I have previously used for analysing individual border crossings and citizenship transitions, to territorial border shifting. The two phenomena are sometimes compared with each other, when secession is described as the migration of borders over people. From a constellation perspective, it is more appropriate to imagine secession as the migration of a polity to a new territorial level. It is thus a specific instance of the broader phenomenon of territorial rescaling, "which refers to the migration of functional systems, identities, and institutions to new levels" (Keating 2013, p. 22).

As I will discuss in section 6, secession within a multilevel constellation involves four types of recognition claims: internal recognition by the citizens of the candidate polity and three forms of external recognition: parental recognition by the parent polity, vertical recognition by a higher-level encompassing polity and horizontal recognition by other polities in the constellation whose status secessionists aspire for. For each secession claim we need to consider which are the polities that are addressed or affected. For example, when examining secession of a province from a state, the relevant constellation will include the parent state, the other provinces of that state and the international community of states from which the secessionists expect recognition. By contrast, when secession changes the boundaries between provinces inside a state, the 
relevant constellation will generally not include third countries. A constellations perspective is not only useful for empirical analyses of secession dynamics, but also essential for normative evaluation. Whatever the motives of secessionists are, they claim a right to change the status or affiliation of a political territory. Such a claim needs to be assessed by considering how it would affect the self-government rights of all the territories involved in the relevant constellation and whether it deserves to be recognised by them.

In order to understand secession as an (attempted) move within a constellation of territorial polities, we need to assume that these polities are otherwise stable. The dissolution of the Soviet Union and Yugoslavia created a context for the formation of new states that is quite different from that of Scottish or Catalan secession attempts. Brexit would also look very different if it happened in a context where the EU itself were in a process of dissolution. A constellations perspective considers secession as a move by one player (in response to other players' moves) rather than as an entirely fresh start of the game. Presupposing otherwise territorially stable democratic polities reduces the number of empirical cases dramatically with regard to international secessions, which have mostly occurred in the context of break-ups of autocratically ruled multinational states or postcolonial independence (Roeder 2007, pp.5-9). ${ }^{1}$ This condition is, however, much less constraining for sub-state secessions that are not infrequent in democratic states. In any case, in order to analyse the democratic legitimacy of secession, we need to assume not only that the polities in the constellation are governed democratically, but also that the constellation itself is relatively stable.

\footnotetext{
${ }^{1}$ There is a second reason for distinguishing cases of democratic secession from those of postcolonial independence. Unlike the former, the latter involves a normatively well-supported primary right to selfdetermination that is also recognized in international law. There are mixed cases, such as the claim for independence of New Caledonia from France. In such contexts, the substantive and procedural principles proposed in this paper have to be modified by taking into account the special weight of indigenous selfdetermination rights.
} 
Relations between polities in a stable constellation are of two basic kinds. They are vertically nested if the territory and citizenry of a polity is included in an encompassing one, as is the case for municipalities and provinces within states and for member states in a union of states. Or they are horizontally distinct if the polities enjoy equal status and their territory and citizenry are generally separate from each other, as is the case for independent states within the international state system. ${ }^{2}$ Within each of these basic types, we need to distinguish two subtypes. Vertical relations are either constitutive or non-constitutive. I will argue in the next section that relations between federal and federated polities, and between member states and unions are constitutive, whereas those between municipalities and the encompassing state or between provinces and a union of states are non-constitutive. Horizontal relations between polities are either embedded or disembedded. The former is the case if all polities are included in an encompassing one, as in intra-state relations between municipalities and provinces and intraunion relations between member states, whereas relations are disembedded if there is no such encompassing polity, as in international relations between states, or in the relations of municipalities and provinces to similar polities in other states. The point of making these conceptual distinctions is that they become normatively relevant when assessing conditions for legitimate secession.

Although most normative theories frame secession as exit from a parent territory, this does not adequately describe the goals and outcomes of secession in multilevel constellations. There are three kinds of changes that secession can (aim to) bring about. The first and most

\footnotetext{
${ }^{2}$ Depending on how polities determine their citizenry, however, this does not exclude partial overlaps. In the international system, individuals retain their citizenship of origin when residing in the territory of another polity and increasing numbers are even dual citizens.
} 
important one consists in upgrading a territory on a vertical scale within a nested constellation. ${ }^{3}$

This happens when a part of a metropolitan region wants to form a separate municipality with its own local government, when a large city or a contiguous group of municipalities wants to separate from the surrounding region by forming a new province, and when an autonomous region or province wants to break away from the state by becoming an independent country.

The second type of change consists in a horizontal realignment ${ }^{4}$ of a territory that secedes in order to join a neighbouring one while retaining its status on the vertical scale. The June 2017 decision of the Swiss municipality Moutier to leave the canton Berne and join the canton Jura provides a recent illustration. The same kind of horizontal transfer happens in the international arena when an irredentist province secedes from one state in order to join a neighbouring one. ${ }^{5}$ Realignment moves can be split into two steps: a secession and a unification move. In order to reduce complexity, I have already set aside territorial unifications and therefore do not further consider realignments either.

Finally, the third type of secession involves exiting without upgrading or realignment. Such pure exit means that a territory is no longer included in a larger one and that its postsecession status does not depend on recognition by other polities. This applies in practice only to states leaving a territorial union of states, such as the EU. ${ }^{6}$ In spite of the claims of Brexit-

\footnotetext{
${ }^{3}$ According to Philip Roeder, 'new nation-states have mostly come from administrative upgrade of segment-states' (Roeder 2007: 11). I extend this idea here to within-state secessions.

${ }^{4}$ The notion of population or territorial transfers is generally used to refer to top-down arrangements that are neither initiated, nor desired by the population concerned, which is why I use the more neutral term of territorial realignment.

${ }^{5}$ Cases in recent history are extremely rare. The annexation of Crimea by Russia does not qualify as it was carried out by military intervention. A plebiscite held ex post under such conditions cannot confer legitimacy to a forceful territorial transfer.

${ }^{6}$ As I am interested here in territorial secession, I do not discuss state withdrawal from international organisations (IOs). Unlike IOs, the EU has a common citizenship and a territory in which it exercises
} 
supporters that Britain will regain sovereignty, Brexit will not lead to any upgrading because the UK was internationally recognised as an independent state while an EU member and will continue to enjoy this status after leaving the EU. Brexit does not involve territorial realignment either since there is no other union of a similar kind that Britain could join. Among the three secession moves, exit from a union of states is therefore the only case that can be compared to individuals leaving a voluntary association: their legal and moral status as autonomous persons does not change and they are free to join other associations or not do so. The world of territorial polities is generally not structured like this. In this world territories can change status and be realigned, but can never fully opt out. Only if states themselves form a territorial union amongst each other is there a possibility of exit without upgrading and realignment.

\section{Democratic Constraints on Secession}

The above observation suggests a basic flaw of plebiscitary secession theories: they consider all democratic polities as voluntary territorial associations of citizens and defend a primary right to secession as an exit right. If this view were correct, then the same permissive rules for secession ought to apply to democratic polities at all levels and independently of the constellations in which they are embedded. In this section I discuss three reasons for a general democratic presumption against a primary right of unilateral secession: territorial stability, democratic diversity and external recognition. In the following sections I will then show that the strength of the presumption varies across territorial levels.

rather comprehensive jurisdiction. Other regional unions, especially those in South America, are gradually evolving towards regional polities with a common citizenship. 
Those who advocate more generous rights of territorial self-determination complain that international law and authors defending remedial-only secession rights are biased towards the status quo in a way that is morally objectionable (e.g. Walker 2017, p.38). The first part of this argument is correct. All established territorial polities are biased towards their self-preservation. Such a preservationist bias is, however, justifiable from a democratic perspective since the democratic legitimacy of collectively binding decisions that affect future members and residents in a territory depends on rough continuity of the territorial borders and composition of the citizenry.

Some proponents of a plebiscitarian right to secession respond that present borders are widely considered to be unjust and permitting iterative plebiscites on unilateral secessions would lead to a series of changes resulting in political borders that are both just and stable (Pogge 1992; Wellman 2005). The latter assumption seems far-fetched, since it underestimates the instrumental use of secession threats as a minority veto (Buchanan 1998: 21) and presupposes that people have stable preferences with regard to territorial units of which they want to be citizens without knowing in advance what the borders of these units will be after a whole series of secessions.

The second democratic objection against a primary right to secession challenges the idea that borders would be just if democratically chosen. It rejects the underlying ideals of political communities as either homogenous nations or voluntary associations. Both are at odds with accepting diversity as a background condition for democracy.

As I have argued elsewhere, an internal diversity of interests, identities and ideas about the common good belongs to the circumstances that make democracy empirically possible and normatively necessary (Bauböck 2017: 7-8). Diversity can be undermined in two ways: through 
government coercion that oppresses, expels or assimilates minorities; or through citizens sorting themselves into more homogenous polities via migration or secession. Of these two sorting mechanisms, only voluntary migration is fully compatible with principles of liberal democracy and it mostly results in more rather than less diversity. If people can move freely across political borders, they do not tend to sort themselves into more homogenous territorial units but seek instead opportunities or protection for themselves and make their territories of destination more diverse as a result. This is not the case where territories are divided either top down or through democratic referendums in order to resolve conflicts over identities and interests by creating more homogenous polities.

Liberal nationalists such as David Miller defend the view that territorial sorting through unilateral secession can be overall beneficial for building stable democracies if it produces nation-states that are better able to support a shared public culture and national identity than multinational states (Miller 2000, pp. 110-124). Yet the purpose of creating a shared culture and identity through territorial separation from an existing polity conflicts with fully accepting diversity as a background condition for liberal democracy. Miller's argument relies on the untested assumption that democracy can and must accommodate a diversity of religious and ethnic identities and ways of life but cannot accommodate a diversity of national identities and nation-building projects unless these share a sufficiently strong encompassing national identity. This argument does not only cast doubts on the stability of multinational democratic states, such as Canada, Spain, the UK, Belgium and India, but also on the project of building democratic unions of states like the EU. Even if we accept the dire empirical prognosis, the problem remains that, once population transfers are ruled out, creating new polities on the basis of national majority identities also creates new alienated minorities and thus reproduces the original problem 
of how to build a public culture and identity that can be shared by all citizens. Moreover, if redrawing territorial borders succeeds in reducing national diversity within polities it will also enhance perceived national differences between them and may thus threaten peaceful and friendly international cooperation.

Associative plebiscitarian theories, while not being committed to nationalism, propose a principle that would have an even more radically homogenising effect: "The reiterated use of the majority principle to settle disputes about political borders ... maximizes the number of individuals who live in mutually desired political association, an ideal implicit in the right of freedom of association" (Beran 1989: 39; see also Gauthier 1994: 360). The problem with this view is that it blurs the distinction between civil society, which is the realm of free association, and political society, which is not. Territorial polities are coercive rather than voluntary associations, whose democratic legitimacy does not emerge from individual consent to membership but from opportunities of contestation and democratic authorisation of governments by free and equal citizens. True, individuals must be free to leave, but this does not imply the freedom to change the shape of the polity itself by breaking away a part of its territory.

The alternative view to a nationalist sorting of heterogenous identities into more homogenous ones and the libertarian dream of people sorting themselves into like-minded political communities is to regard diversity as a background condition, rather than an obstacle for democracy. The fact that people are thrown together through accidents of birth in a territory whose borders have been shaped by history instead of their own choices, is not to be regretted in this view. Democracy is a system of political rule that can be justified towards such people because it treats them as free and equal citizens who jointly authorise a government that has coercive powers to resolve their conflicts and pursue their common interests. 
Moreover, preserving and affirming a persistent diversity of interests, identities and ideas requires constitutional democracy rather than simple majoritarian decision-making. A voluntary association of like-minded people can be internally democratic in the sense of having a governing board that represents its members and is accountable to them, but it does not need a constitutional democracy whose government is constrained by checks and balances and the rule of law. Constitutional democracy in turn preserves individual liberties and minority rights against majority tyranny. ${ }^{7}$

The third democratic constraint on secession is a requirement of recognition within the relevant constellation. As I will argue in section 6, only for candidacy recognition is there a strict requirement of actual support. For the three types of external recognition introduced in section 2, the normative condition is not that other polities must actually recognise a secession claim, but that they ought to do so because the claim is 'recognition-worthy'. While being worthy of external recognition is a condition for the legitimacy of secession, achieving actual recognition is a fundamental interest of the citizens of a newly created polity. Without recognition by other polities, a seceding territory would become an outcast or 'liminal polity' (Krasniqi 2018, in this issue) - similar to a stateless person in a world where the rights of individuals depend on states recognising them as citizens of a particular country.

Secessionists assume that they have a moral claim to vertical or horizontal recognition by virtue of a unilateral right to self-determination. For example, Catalan and Scottish separatists want post-secession states to be immediately recognised as new member states of the EU and also of the UN. Their opponents claim that secession has to be recognised first of all by the

\footnotetext{
${ }^{7}$ The view that plurinational diversity is a favourable condition for liberal democracy was defended by Lord Acton in his rebuttal of John Stuart Mill's nationality principle (Acton 1907).
} 
parent polity and that this presupposes either a constitutional right or legislative permission to hold a secession referendum in the candidate territory or alternatively approval by a majority of voters throughout the parent territory. Both of these stances are insensitive to level-specific conditions for recognition. As I will discuss below, normative conditions for recognition vary strongly across levels. Here I emphasise the general point that a requirement of external recognition contradicts claims to unilateral self-determination by framing the legitimacy of secession in relational terms. ${ }^{8}$ Secession is morally legitimate only if the other polities in the constellation are obliged to recognise an upgrading or realignment claim for a particular territory.

The territorial stability, democratic diversity and recognition requirements all highlight why the analogy with voluntary association is inappropriate when assessing the normative legitimacy of territorial secession. But these constraints create only a general and defeasible presumption in favour of existing borders. After all, it is theoretically possible that redrawing them might enhance stability, preserve diversity and result in mutual recognition between the newly created polity and the others in the constellation. In order to arrive at more determinate answers to the question of when secession is legitimate we need to examine the properties of democratic polities at different levels and their relations to each other.

\section{Democratic Purposes of Citizenship and Self-government at Different Levels}

In this section I provide a normative argument for a multilevel framework by examining the specific democratic purposes of polities at different territorial levels. I derive this argument from a theory of multilevel citizenship that I have elaborated elsewhere (Bauböck 2017). I suggest

\footnotetext{
${ }^{8}$ See also Keating (2013, p. 175), who similarly defines territorial autonomy as "a relational concept, so that all polities are self-governing but interdependent."
} 
there that individuals' claims to be recognised as citizens of a specific polity depend not only on the strength of their ties to it, but also on the conditions under which this polity can govern itself. These conditions differ fundamentally for polities that occupy different rungs on the vertical scale within nested constellations. I propose that (1) at the local level, all residents are local citizens and should also enjoy voting rights in local elections; (2) at the independent state level, citizenship is attributed at birth and presumptively retained for life rather than being automatically acquired and lost on the basis of residence; (3) citizenship in self-governing regions (of a federal state or regions enjoying special autonomy status) is derived from citizenship of the wider state and activated through residence in the region; (4) the same principle of derivative citizenship activated through residence applies to unions of independent states, such as the EU, with the difference that here citizenship in the encompassing polity is derived from that of the constituent member states.

The normative argument backing these level-differentiated principles for determining citizenship is that different types of polities and citizenship regimes realise different democratic purposes. The local level of government in democratic states provides public goods and services to residents in polities with completely open borders. The territorial integration of states has torn down the walls around cities and abolished privileges of local ancestry and birth. It has thereby created an open space in which mobility does not affect one's citizenship status and rights. All sufficiently large democratic states have, however, retained local powers of self-government. The combination of these two features of local democracy - open borders and self-government realises an important democratic purpose: it turns co-residents into equal citizens without distinguishing between natives and foreigners. This is not only a value for the local community; since the whole state territory is subdivided into self-governing municipalities, an inclusive 
residence-based citizenship exists throughout the national territory and provides a first and basic layer of democratic citizenship.

Citizenship in independent states is regulated by very different principles. It is based on acquisition by birth (through descent from citizens or birth in the national territory) and life-long membership by default. Immigrants who want to become citizens have to reside in the territory for longer than in the local community and they do not become citizens automatically but have to apply for naturalisation. The converse rule exists for renunciation of citizenship by emigrants, who can give up their citizenship only after taking up residence abroad and filing a request. This regime may look more exclusionary than automatic ius domicilii at local level, but this depends entirely on what the conditions for naturalisation are. Moreover, life-long birthright citizenship provides migrants with a secure external citizenship and right to return to their country of origin, which they would lose if their citizenship depended on residence.

The democratic purpose that is sustained by these rules for national citizenship is, first, the long-term stability and transgenerational continuity of the citizenry. This is important when citizens are asked to take into account the interests of future generations who will be members of the same polity. Second, birthright and life-long citizenship stabilises also the responsibility of independent states for their citizens in a way that protects the interests and rights of individuals who move across borders in the absence of an encompassing polity. Democratic states readmit their citizens from abroad, they provide them with diplomatic protection and most involve them also as absentee voters in national elections, none of which would be compatible with a system of purely residence-based citizenship in a world of nation-states that control their borders.

The third way of determining citizenship status is by derivation. The citizens of California are those US citizens that reside in the Golden State. And the citizens of the EU are 
the nationals of the member states. In the vertical hierarchy of nested polities, citizenship is derived downwards in the first case and upwards in the second one. However, it is always derived from the same level: independent state citizenship determines who is a citizen of a substate province as well as of a supra-state union. Both local and regional citizenship at sub- and supra-state levels complement the weightier status and more comprehensive rights of national citizenship. However, local citizenship is structurally disconnected from national citizenship, whereas regional citizenships below and above the state level are structurally connected to it.

There is again an important democratic purpose that is articulated and supported by such derivative citizenship regimes: (federal) union. Most large-scale democratic states have a regional layer of self-government in between the local and national ones. In federal states, this layer is involved in a constitutive relation with the larger polity that combines regional autonomy with power-sharing in the federal government (Elazar 1987, Stjepanovic and Tierny, in this issue). Federal democracy keeps a check on majority tyranny, because it adds a vertical division of powers between federal and federated polities to the separation between branches of government (Madison 1982). The common feature that distinguishes these arrangements from those of local self-government is that they are constructed as unions of autonomous polities that could potentially be independent from each other but are bound together by a commitment to share a common destiny and to govern jointly. Understood in this way, sub-state regional selfgovernment, be it through a federal constitution or a special autonomy status for offshore islands or regions with a culturally distinct majority population, is also a response to John Stuart Mill's question of how different nationalities can be united under a democratic government (Mill 1972: 391-8). 
Derivative citizenship effectively means that regional citizens enjoy territorial autonomy because they are also citizens of the larger polity and are thus bound to respect the territorial integrity of the state as long as it preserves their collective autonomy. Similarly, it signals to the citizens of a union that they enjoy their rights of free movement because they are citizens of a member state and should thus support their state's membership and contributions to the union.

The specific purpose realised by a union of states that is not a federation but a 'demoicracy' is that is allows states to better serve their citizens by 'governing together but not as one' (Nicolaidis 2013, Cheneval and Schimmelfennig 2013). Different from the provinces of a federation, the member states of a union retain their fundamental status as independent members of the international state system, but at the same time create a common legal order and government institutions in order to preserve the conditions for peace among, and democracy within the member states, and to enable them to address problems that would overwhelm them if they had to resolve them separately.

The upshot of the argument in this section is that the rules for determining citizenship at the four territorial levels realise simultaneously and in a complementary way the democratic purposes of inclusive membership for co-residents in mobile societies, of transgenerational continuity of the citizenry and secure lifelong citizenship for international migrants, of regional autonomy within and of pooled sovereignty across states. It is impossible to pursue and combine these purposes at the national level alone. A mono-level conception of democracy is deeply flawed for this reason.

\section{Substantive Legitimacy Tests: territorial integrity and democratic purposes}


I will now consider conditions under which the different secession moves discussed in section 2 could be considered legitimate from the perspective of multilevel democracy outlined in section 4. I will again focus on the characteristics of territorial self-government at each level in order to consider whether the encompassing polity is constituted as a voluntary association, whether its democratic purposes justify restrictive or permissive rules on secession and what constraints emerge from the secessionists' need for recognition. These questions provide us with a sequence of three legitimacy tests: a voluntary association test establishing whether or not there is a primary right to secession, a democratic purpose tests clarifying what substantive grounds must be invoked as reasons for secession if there is no primary right, and various recognition tests specifying procedural requirements for legitimate secession. I will discuss substantive tests in this section and procedural recognition tests in the next.

My argument will deliberately blend empirical facts with normative principles. We have now arrived at a level of contextuality where normative theory cannot remain purely deductive. Already my previous discussion of general principles of multilevel self-government was heavily informed by the evolution of democratic polities towards their present features. However, this argument was still decontextualised in the sense that it aimed at principles that apply to all contemporary democracies. Once we consider how democracies should respond to secession claims we need to consider also the particular constellations within which they are embedded and their position therein, and these are not the same everywhere. Not all democratic states are, or have to be, members of a supranational union; not all are plurinational in the sense of having been shaped by the historic co-presence of several nation-building projects in their territory, etc. At this level of analysis it is appropriate to consider also how international law or democratic constitutions, courts and governments have responded to secession claims. The task of normative 
theory is then to go back and forth between principles and practices until we reach a reflective equilibrium. $^{9}$

I have claimed that all polities have an interest in their territorial integrity. Whether this interest is strong enough to rule out a unilateral right to secession depends on the constitution of the polity, and specifically the relation between an encompassing polity and the nested polities within its territory. Where the relation is a confederal one or a union of independent states, the encompassing polity has been constructed as a voluntary association, each of whose members has freely joined and remains free to leave. The citizens of the union may have an interest in preserving the territorial integrity of the larger polity, but they cannot prevent any of its constituent parts from opting for exit without destroying the constitution that binds them together. The EU is a polity of this kind. Its nature as a voluntary association of states emerges from the rules for accession of new member states (Art. 49 TEU). Even before the insertion of Art. 50 on withdrawal from the Union in the Lisbon Treaty, it was generally understood that member states were free to exit. What this latter article does is to establish a procedure for leaving the EU. In normative terms, it affirms an already implicit right to secede, but makes its exercise conditional on a readiness to negotiate fair terms of separation. This imposes reciprocal obligations on the EU to offer such fair terms instead of deliberately punishing the citizens of a withdrawing state and on the government of the withdrawing state to seek an agreement instead of pulling out without a deal.

Federal states are fundamentally different from confederations and demoicratic unions in this respect. A federation has, first, a consolidated territory instead of a procedure for enlargement that establishes a right to join for qualifying countries subject to agreement by the

\footnotetext{
${ }^{9}$ This use of 'reflective equilibrium' differs somewhat from John Rawls' conception (1971, pp.48-51), which goes back and forth between moral principles and intuitions, rather than democratic principles and practices.
} 
present member states (Lacey and Bauböck 2017). ${ }^{10}$ Second, the purpose of a democratic federation is to bind together self-governing polities that could potentially be independent states into a common polity that is itself an independent state.

We can describe the moral compact that sustains federal cohesion as a double conditionality of territorial self-government: As long as the federal government respects the selfgovernment rights of the constituent polities, the latter are bound to respect the territorial integrity of the federation. Conversely, if the federal government violates systematically the autonomy of constituent polities and there are no alternative constitutional remedies for restoring it, these polities have a right to threaten with secession. Ideally, federal constitutions specify these rights fairly because they have emerged from a unanimous consensus among constituent polities. Ideally, federal courts will be neutral arbiters in conflicts between central and federated governments over the interpretation of these rights. And, ideally, federal constitutions will be open for renegotiation when they are no longer sufficiently supported by all polities in the federation (Tully 2001). Under non-ideal conditions, constitutional documents and courts will often fail to protect the self-government rights of federated polities adequately.

The proper normative approach to secession in such cases is thus a remedial-right only conception, with a specification of the relevant grievance as the violation of territorial selfgovernment rights. What counts as an alternative remedy depends on the nature of the secessionists' grievances but also on the nature of the regime in power. If a territorial minority has suffered persistent suppression by a non-democratic regime, its leaders may have good reasons not to trust remedial autonomy offers. If, however, there is a change towards a

\footnotetext{
${ }^{10}$ The territorial expansion of the US federation was not a procedure of voluntary association, but of colonisation and eventual upgrading of territories into states. Puerto Rico might eventually become the $51^{\text {st }}$ state, but this option emerges from its current non-self governing status that is not compatible with the US constitution.
} 
democratic regime and they are invited to negotiate a new constitution, past grievances alone cannot justify secession. The secession of Kosovo from Serbia illustrates the former scenario, the Spanish transition to democracy after Franco's death the latter. ${ }^{11}$

I am not taking sides here in the debate over whether such a remedial right to secession ought to be formally enshrined in the constitutions of federal states alongside the primary rights to territorial self-government. The debate on constitutionalising secession rights has focused on the consequentialist question of whether doing so is likely to enhance or undermine federal cohesion (see e.g., Norman 2002; Sunstein, 2001; Weinstock 2001). My claim is a normative one that the constituent polities of federal states have a moral right to secede if and only if their rights to self-government are violated in a way that destroys the federal nature of the constitution. One might object that such a remedial secession right may still infringe on the rights of the remaining constituent members of the federation that are worse off after secession. However, if the purpose of the federation is to preserve the self-government rights of all its constituent members, then negative consequences for the remaining polity are a self-inflicted harm that cannot trump a right to secede. ${ }^{12}$

This raises the question of how to assess cases where the constitution is not fully federal (as in the UK and Spain) or where a territory has been granted special autonomy status. The answer is that the same principle must also apply to these cases. Where a particular territory is integrated into a (non-federal) state based on an agreement that its autonomy will be protected by the constitution of that state, it is the violation of this autonomy that potentially legitimates a secession claim. Finally, the question may be raised whether a more permissive stance of a constitution or central government on secession is legitimate. In the UK, Northern Ireland has

\footnotetext{
${ }^{11}$ I thank David Owen for pushing me to clarify this point.

${ }^{12}$ I thank an anonymous reviewer for this question.
} 
been granted an explicit right to secede and realign with the Irish Republic if a majority of the citizens of the province vote for this change, whereas the Westminster Parliament granted Scotland only a temporary permission, which expired at the end of 2014 , to hold a referendum on independence (Skoutaris 2017). Nothing I have said above rules out such permissions, which in the Northern Irish case is also supported by the duty of the UK to remedy ongoing effects of its past colonial rule over Ireland and of partition in 1921. But no general duty to allow for unilateral secession can be derived from a few countries creating such a right.

What about within-state secessions that create new autonomous provinces? My general argument in section 3 in favour of territorial stability and democratic diversity implies again a presumption against considering these as unilateral rights. However, notice that the diversity argument applies in fundamentally different ways to secessions within and from states. Imagine a country where a linguistic minority is strongly concentrated within a particular territory but where this territory does not have self-governing status because it is merged into a larger province dominated by national majority language speakers. In this case, the linguistic minority may rightly feel that, in the absence of powers to establish their idiom as the dominant public language in their territory, there is a risk that the language will fade away. ${ }^{13}$ Subdividing the territory by permitting secession may in this case preserve linguistic diversity in the encompassing polity. If the same territory would instead secede from the larger state and form a new country, there would be no more common polity within which this diversity can be recognised and accommodated. The goals of accommodating diversity and preserving minority cultures can thus be reconciled through redrawing internal territorial boundaries, while the latter goal is sacrificed in international secessions.

\footnotetext{
${ }^{13}$ See Laponce's (1987) argument on why minority languages need territorial powers to survive.
} 
The territorial integrity interest of sub-state polities inside a democratic state are weaker than those of independent states, which are potentially exposed to hostile interference by other states. However, as the above scenario illustrates, the autonomy interests of territorial minorities may support either a claim to internal secession or to preservation of territorial integrity against central government plans to merge them into a larger territory. The goal is thus not to maximise diversity within each sub-state territory, which would rule out creating territories where minorities are concentrated, but to preserve diversity as a stable background at the level of the encompassing polity. The general principle is to accommodate legitimate claims to territorial self-government through subdividing the territory in a way that minimises majority domination.

There are two risks associated with such accommodation. The first is that creating territories where national minorities form a majority will lead to domination of internal minorities within these territories (Eisenberg and Spinner-Halev 2005). If an internal minority does not itself have claims to territorial self-government, then domination can be avoided only by promoting an inclusive public culture and applying liberal constraints on nation-building within the minority territory in the same way as in the encompassing state. The second risk is that accommodating minorities through multinational federalism or territorial segmentation may also empower them to eventually form independent states (Kymlicka 2001, pp. 91-119; Roeder, 2007, Erk and Anderson 2009). The normative argument points, however, in the opposite direction: Depriving minorities of territorial self-government powers potentially justifies their claim to external secession while granting them sufficient powers of self-government obliges them to respect the territorial integrity of the state. This unfortunate gap between normative prescription and empirical prediction can and should be narrowed through constitutional design, for example by giving territorial minorities stronger stakes in the encompassing polity through 
integrating the representatives of territorial minorities into power-sharing institutions at the central government level and ensuring that federal institutions such as Constitutional Courts are not biased towards the central government. ${ }^{14}$

What about secession at the local level? On my account, the democratic purpose of local self-government is fundamentally different from that of territorial autonomy for constituent and potentially independent territories. It is to provide local residents with public services and an infrastructure for their daily lives and economic or cultural activities. As democratic polities municipalities must be responsive and accountable to their residents and treat them as equal citizens when taking political decisions on such matters. These tasks create an interest in territorial integrity that - although it may be considered weaker than that of states or historic provinces - once again defeats a presumptive unilateral right of secession.

Suppose a city government needs to impose a certain level of local taxes in order to finance an adequate infrastructure. Residents living in a wealthy suburb bordering on a rural municipality with much lower tax rates campaign for secession and realignment with their rural neighbours in order to avoid paying taxes for the infrastructure that they would continue to use because of the city's open borders. This example illustrates a general principle that local territorial borders should match social patterns of settlement and activities of inhabitants (Bauböck 2003). Cities have a legitimate interest in including in their borders wider metropolitan regions under a single layer of government and can rightly oppose opportunistic secessions on this ground. ${ }^{15}$ For the same reasons, where a provincial or central government unduly curtails a

\footnotetext{
${ }^{14}$ The absence of such integrating mechanisms in the Spanish case may have contributed to the escalation of Catalan autonomy claims towards secessionism.

${ }^{15}$ By contrast, plebiscitarian secession theories must regard such instrumental reasons as legitimate.
} 
city's attempts to develop its urban infrastructure and public services, the city might attempt to secede by campaigning for an administrative upgrade into an autonomous province. ${ }^{16}$

\section{Procedural Legitimacy Tests: recognition claims}

The purpose of the substantive tests outlined above is not to determine conclusively whether secession is legitimate. This is only possible for exit from a confederation or union of states. In all other contexts, the substantive tests yield different degrees of presumptive legitimacy for claims to territorial integrity or secession. The task of the procedural tests is then to specify how such necessarily vague assessments could be translated into a set of procedures that are likely to produce legitimate outcomes. The search for pure procedural legitimacy ${ }^{17}$ is, however, futile, as the substantive criteria discussed in the previous section determine what procedures we should be looking for in each type of polity.

Of the four relations of recognition introduced in section 2, candidacy recognition is the only condition that applies universally to secession claims at all levels and in the same way. If political leaders, parties or governments call for secession of a territory, they are making a representative claim (Saward 2010) to speak on behalf of a constituency residing in the territory. Such a claim is spurious if it is not supported by the constituency. Its representativeness may also be contested if it is made on behalf of only a part of the resident population (e.g., a titular

\footnotetext{
${ }^{16}$ A proposal to turn Toronto into a federal province has been on the political agenda since the 1970s. See: https://en.wikipedia.org/wiki/Proposal for the Province of Toronto.

${ }^{17}$ Pure procedural legitimacy would be similar to Rawls' concept of pure procedural justice, which refers to situations 'in which there is no independent criterion for the right result: instead there is a correct or fair procedure such that the outcome is likewise correct of fair whatever it is, provided that the procedure has been properly followed' (Rawls 1971, p.86).
} 
nationality) and involves non-residents (a diaspora). Democratic procedures are therefore required in order to establish that the claim is representative.

A second consideration provides the answer as to what kind of procedure is required. Secession, even if we understand it as an upgrading of the self-governing status of a territory, creates a new demos. It follows that a representative claim cannot be recognised in the same way as most other political decisions in representative democracies, which is by majority vote in a legislative assembly emerging from free and fair elections. If the decision is about whether a new demos will be constituted, then a vote by the representatives of the already constituted demos is not sufficient. Only the citizens of the contested territory themselves can provide candidacy recognition through a referendum on secession. ${ }^{18}$

It is, however, important to clarify that the citizens voting in a secession referendum are not necessarily identical with the constitutive demos of a newly formed polity. First, before the vote it is impossible to know with certainty which way the decision will go. The composition of the demos voting on secession can therefore not be based on the outcome of a decision that is still to be taken by the very same demos. ${ }^{19}$ Second, in case of eventual secession, the final borders may be a matter of negotiation with the parent polity. If they are redrawn, they will include a constitutive demos that is not identical with the one enfranchised in the referendum. Finally, a referendum on secession must not be gerrymandered in order to make the desired result more likely, either by including territories where citizens are inclined to vote against secession or by excluding those that are likely to be opposed. The upshot of these considerations

\footnotetext{
${ }^{18}$ The dissolution of Czechoslovakia in 1993 based on decisions by the political leaders of the two federated republics and ratified by the federal parliament was therefore illegitimate from a democratic perspective. This assessment is reinforced by evidence that at the time of separation a majority of citizens in both parts of the country would have voted against it (see the sources quoted in Roeder 2007, p.25). ${ }^{19}$ The general point is made by Goodin (2007). For a discussion of the franchise in the Scottish 2014 referendum see Ziegler et al. (2014).
} 
is that a secession referendum must be held in a candidate territory whose borders are already well defined and it must involve the same voters who are already recognised as citizens of the territory prior to secession or who have a claim to be so recognised (which may include a diaspora that has been recently coercively dislocated and may exclude settlers brought recently into the territory in violation of the local population's self-government rights). ${ }^{20}$ This argument provides further support for my initial conceptual claim that secession is an attempted political upgrading of an existing territory rather than the voluntary formation of a new political association.

In contrast with candidacy recognition, parental recognition is not a universal requirement in the sense of either a duty to grant or a right to withhold recognition. This follows straightforwardly from the discussion of substantive legitimacy criteria in the previous section. Opportunistic secessions and those that violate the territorial integrity of the parent polity in the absence of a sufficiently strong grievance do not have to be recognised by the latter even if they are supported by a clear majority of the candidate territory's citizens. The interesting empirical question is what procedures in democratic states make democratic support in the parent territory a condition for secession. One such procedure is contained in article 29 of the German Constitution, which regulates the redrawing of internal borders between the German Länder. Consider a hypothetical scenario where the culturally and historically distinct region of Franconia wants to secede from Bavaria and form a new Land. Art. 29 stipulates first a substantive test of taking into consideration criteria such as regional cohesion, historic and cultural identity, economic and administrative efficiency, which an initiative for a new Land

\footnotetext{
${ }^{20}$ For a more extensive discussion see Stjepanovic and Tierny (2018, in this issue). See also Arrighi (2018, in this issue) for an empirical explanation of why secessionists in Scotland and Catalonia, in spite of their somewhat different approaches to franchise issues, have broadly accepted these normative requirements.
} 
Franconia might plausibly meet. A referendum on a bill about the change of status and borders would have to be held in all of Bavaria. The decision is for secession of Franconia if $1 / 4$ of the electorate participate in the vote and if there are either simple majorities in favour in both Franconia and in all of Bavaria or a 2/3 majority for secession in Franconia and no 2/3 majority against it in all of Bavaria. This complex procedure combines candidacy with parental recognition, giving the parent polity a qualified veto power over secession.

I do not know of any similar procedure for a constitutional right to international secession. In the recent Catalan secession crisis, however, Spanish Prime Minister Mariano Rajoy stated that a referendum on the independence of Catalonia would be legitimate only if it were held in all of Spain. This stance contrasts with the well-known opinion of the Canadian Supreme Court, ${ }^{21}$ which concluded that a clear majority on a clear question in a referendum held in the province of Quebec alone would trigger a duty of the federal government to enter negotiations with the province that might - although not necessarily so - result in independence. It also contrasts with the British Parliament granting Scotland a temporary right to hold a referendum, in which a pro-independence vote would have been politically binding. These three different stances have been sometimes misinterpreted as indicating a lack of consensus across democratic states on whether there is a unilateral right to secession without parental recognition. This is clearly wrong, as the Canadian Supreme Court unambiguously states that there is no such right in the first place. The differences are instead over the question of how parental recognition must be expressed in order to make secession legitimate: in the same coin of democratic majority support as for candidacy recognition (Spain), through legislative ex ante permission for a referendum in the candidate territory (UK), or as the result of executive negotiations after a proindependence vote in that territory (Canada)? Given this variation of democratic practices, it is

\footnotetext{
${ }^{21}$ Reference Re Secession of Quebec Sup. Ct. of Canada 2 S.C.R. 217.37 I.L.M. 1340 (1998)
} 
unpromising to postulate a general procedure for parental recognition that ought to be followed in all cases. However, the substantive principles proposed in section 5 for external secession provide at least some indications for what conditions are impermissible. Where a central government has persistently violated the self-governing rights of a territory it cannot respond to a secession threat by insisting that such a decision must be taken by the demos of the encompassing polity. The burden is then first on the secessionists to establish that their grievances amount to such a violation and, if this can be confirmed, shifts to the central government that must offer alternative remedies, such as constitutional reform, if it wants to preserve the territorial integrity of the state.

Moving on to vertical and horizontal recognition, I want to illustrate these again with an empirical example. The creation of the canton Jura followed a procedure that was quite different from the one foreseen by the German Constitution. After a partly militant struggle by Jurassian separatists, three referendums were held in 1974 and 1975 in which mostly Francophone municipalities in the northern parts of Canton Berne voted to establish a new canton. The decisive condition in this case was not parental recognition by Berne, but vertical recognition by the Swiss federal demos, which voted in September 1978 for the new canton Jura that was duly admitted into the federation in 1979. Since a fully federal constitution involves not merely autonomy of constitutive territories, but also extensive power-sharing in federal institutions, regional-level secession amounts to an 'internal enlargement' that affects the federation as a whole and its institutions. The Swiss formula for federal referendums requires a double majority among all enfranchised federal citizens as well as in a majority of cantons, which implies thus a further threshold of horizontal recognition in the procedure of legitimising internal secession. 
The Swiss example contrasts with the Indian Constitution's rule for the formation of new states (Article 3), which requires only vertical recognition through decision by the Indian Parliament after taking the view of the affected state legislature into account, but without testing either candidacy or horizontal recognition, which makes the change of internal borders a rather arbitrary power of the central state.

Some authors have applied the idea of internal enlargement to the EU arguing that an independent Scotland or Catalonia would not have to apply for accession under article 49, but could instead continue to be included as EU territories through a Treaty revision according to article $48 .^{22}$ As correctly stated by Requejo and Nagel (2017) this is only plausible if the EU is regarded as a federation in the making. According to the multilevel approach presented in this paper, such a view misunderstands, however, the nature of the EU, which is a voluntary association of independent states. From this latter perspective, Brexit as well as potential decisions for Scottish or Catalan independence put these territories outside the Union. The fact that EU law had been deeply entrenched in all these polities while they were inside should facilitate negotiations about terms of separation in the former case and of accession in the latter, but it does not affect the question of membership status itself.

Let me finally consider briefly the horizontal recognition of newly formed states in the international system. While international law does not acknowledge a right of self-determination for nations that are not already constituted as states or for territorial majorities that want to secede (Cassese 1995), past practice has mostly been that newly formed states are eventually recognised if they exercise effective sovereignty. The redrawing of international borders has been, however, strongly constrained through the principle of uti possidetis iuris (Ratner 1996), which is often condemned as entrenching borders designed by colonial powers or authoritarian

\footnotetext{
${ }^{22}$ See various contributions in Closa and Vintila (2015).
} 
predecessor regimes. From the perspective defended in this article, the latter critique is misguided. Conceptually, as well as normatively, secessions should be understood as claims to upgrade the status of existing territorial polities, rather than as a redrawing of borders according to criteria such as ethnicity, language or race. By contrast, the critique of a criterion of effective sovereignty is largely supported. Ideally, states should form their own judgments on whether an international secession is legitimate because of a persistent prior violation of territorial selfgovernment rights. The problem is that foreign states are generally not in a good position to make such judgments. Moreover, international recognition of new states by existing ones is the outcome of a largely uncoordinated process of decisions that are inevitably clouded by domestic concerns about the latter's own restive minorities or foreign policy concerns about how recognition will affect their relations with the parent state. In the absence of a global political authority that would turn all international secessions into internal ones, democratic states ought to promote a stronger role of international jurisprudence and courts, such as the International Court of Justice, which in turn should aim for a progressive evolution of international law on self-determination and state recognition (Buchanan 2004).

\section{Conclusions}

In this paper I have connected a conceptual claim to a normative one. The conceptual claim is that secession should always be understood as an (attempted) change of the status or affiliation of a territory within a multilevel constellation of polities. The normative claim is that the legitimacy of secession depends on whether it can be justified on the basis of the different purposes of democratic polities at local, federated, independent and union levels and whether it 
meets reasonable procedural requirements for recognition inside the candidate territory, by the parent and encompassing polity and by other horizontally aligned polities in the constellation.

My conclusion is that candidacy recognition through a referendum in the territory that tries to break away is a universal condition for democratic secession, but that this necessary condition is a sufficient one (qualified by a readiness to negotiate fair terms of separation) only for member states of a confederation or union of independent countries. In all other cases, the parent polity's interest in territorial integrity creates a presumption against a right to secede. However, the thresholds for relevant grievances, and the procedural conditions for secession vary strongly across territorial levels. Secession from independent states is substantially legitimate if and only if territorial self-government rights of the candidate polity have been persistently violated and there is no alternative remedy. A desire to match territorial with cultural boundaries cannot justify international secession, because the underlying goal of sorting nationally diverse populations into separate polities is pernicious for democracy. By contrast, internal secessions within states may be motivated by attempts to match cultural and social boundaries if this helps to prevent domination of minorities or to unify metropolitan areas under a single government.

I have illustrated different degrees of procedural permissiveness towards international and internal secession, quoting rules applied in Canada, Spain, UK, Germany, Switzerland and India. The task of normative theory is not to be overly prescriptive by picking out best and worst practices, but to use such examples instead for reaching a reflective equilibrium in which the initially chosen principles meet the test of real democratic contexts, while being also refined and modified as a result of the encounter.

Let me conclude on a speculative note. The multilevel theory of secession that I have sketched is premised on the assumption that all polities have clearly demarcated territorial 
jurisdictions. We can imagine alternative or future worlds in which this is no longer the case.

Territory could lose importance if either large majorities of people are constantly on the move without ever settling down for good (Bauböck 2017: 12-18) or if new digital technologies allow for the democratic constitution of governments and the provision of government services on a non-territorial basis (Orgad and Bauböck 2018). In such a fictional world, democratic polities would have to adopt more permissive attitudes towards secession. Political associations might become much more like voluntary associations in civil society, with the effect of increased homogeneity within and increased heterogeneity between polities. Inside such non-territorial polities there might be fewer conflicts that call for democratic resolution, but there would be a much stronger potential for conflicts between them and no political authority that has a democratic mandate from citizens to regulate these. I imagine this world as a dystopia in which democracy and freedom would become harder to sustain.

\section{Bibliography}

Acton, John E. E. Dalberg. 1907. "Nationality." In The History of Freedom and Other Essays, ed. John Neville Figgis. London: Macmillan. 270-300.

Arrighi, Jean-Thomas. 2018. "'The people, year zero': Citizenship and the politics of independence in Scotland and Catalonia" Ethnopolitics forthcoming.

Bauböck, Rainer 2003. "Reinventing Urban Citizenship." Citizenship Studies 7(2): 137-158.

Bauböck, Rainer 2010. "Studying Citizenship Constellations." Journal of Ethnic and Migration Studies 36(5): $847-859$.

Bauböck, Rainer 2017. Democratic Inclusion. A Pluralistic Theory of Citizenship. Rainer Bauböck in Dialogue. Manchester: Manchester University Press.

Beran, Harry 1989. "A Democratic Theory of Political Self-Determination for a New World Order." In Theories of Secession, ed. Percy Lehning. London: Routledge. 32-59.

- - . 1984. "A Liberal Theory of Secession." Political Studies 32: 21-31.

Buchanan, Allen. 2004. Justice, Legitimacy, and Self-Determination. Moral Foundations for International Law. Oxford: Oxford University Press.

Buchanan, Allen 1991. Secession. The Morality of Political Divorce from Fort Sumter to Lithuania and Quebec. Boulder, Co: Westview Press. 
- - - 1997. "Theories of Secession." Philosophy and Public Affairs 26: 31-61.

-- . 1998. "Democracy and Secession", in: Margaret Moore (ed.) National Self-Determination and Secession, Oxford University Press, Oxford: 14-33.

-- - 2004. Justice, Legitimacy, and Self-Determination. Moral Foundations for International Law. Oxford, Oxford University Press.

Cassese, Antonio 1995. Self-Determination of Peoples. A Legal Reappraisal. Cambridge: Cambridge University Press.

Cheneval, F. and F. Schimmelfennig 2013. "The Case for Demoicracy in the European Union. Journal of Common Market Studies." Journal of Common Market Studies 51(2): 334-350.

Closa, Carlos, and Daniela Vintila. 2015. "Supranational Citizenship: Rights in Regional Integration Organizations. Draft Paper." In Secondary Supranational Citizenship: Rights in Regional Integration Organizations. Draft Paper, ed Secondary - - - Florence. Reprint, Reprint.

Eisenberg, Avigail, and Jeff Spinner-Halev, eds. 2005. Minorities within Minorities. Equality, Rights and Diversity. Cambridge: Cambridge University Press.

Elazar, Daniel 1987. Exploring Federalism. Tuscaloosa: The University of Alabama Press.

Erk, J. and L. Anderson 2009. "The Paradox of Federalism: Does Self-Rule Accommodate or Exacerbate Ethnic Divisions?" Regional \& Federal Studies 19(2): 191-202.

Gans, Herbert 1979. "Symbolic Ethnicity: The Future of Ethnic Groups and Cultures in America." Ethnic and Racial Studies 2: 1-20.

Gauthier, David. 1994. "Breaking Up: An Essay on Secession," Canadian Journal of Philosophy, vol. 24, Nr. 3: 357-372.

Goodin, Robert. 2007. "Enfranchising All Affected Interests, and Its Alternatives." Philosophy and Public Affairs 35: 40-68.

Keating, Michael 2013. Rescaling the European State: The Making of Territory and the Rise of the Meso. Oxford: Oxford University Press.

Krasniqi, Gëzim 2018. "Contested States as Liminal Spaces of Citizenship: Comparing Kosovo and the Turkish Republic of Northern Cyprus ". Ethnopolitics forthcoming.

Kymlicka, Will. 2001. Politics in the Vernacular: Nationalism, Multiculturalism, and Citizenship. Oxford: Oxford University Press.

Lacey, Joseph, and Rainer Bauböck. 2017. "Enlargement, Association, Accession - a Normative Account of Membership in a Union of States." Journal of European Integration 39(5): 529-543.

Laponce, J.A. . 1987. Languages and Their Territory. Toronto: University of Toronto Press.

Madison, James 1982. "Federalist 10." In The Federalist Papers (1787-1788), ed. James Madison and John Jay Alexander Hamilton. Toronto: Bantam Books: 42-49.

Mill, John Stuart (1972) 1972. "Considerations on Representative Government." In Utilitarianism, Liberty, Representative Government, ed. H. B. Acton. London: Everymans Library.

Miller, David 2000. Citizenship and National Identity. Cambridge: Polity Press.

Nicolaidis, Kalypso. 2013. "European Demoicracy and Its Crisis." Journal of Common Market Studies 51: 351-69.

Nielsen, Kay 1998. "Liberal Nationalism and Secession." In Self-Determination and Secession, ed. M. Moore. Oxford: Oxford University Press: 103-133.

Norman, Wayne 2002. "Domesticating Secession." In Secession and Self-Determination, ed. Allen Buchanan and Stephen Macedo: Nomos XLV. 193-237.

Orgad, Liav, and Rainer Bauböck, eds. 2018. Cloud Communities: The Dawn of Global Citizenship?, RSCAS Working Paper. Florence: EUI.

Patten, Alan 2014. Equal Recognition. The Moral Foundations of Minority Rights. Princeton: Princeton University Press.

Pogge, Thomas 1992. "Cosmopolitanism and Sovereignty." Ethics 103: 48-75. 
Ratner, Steven R. . 1996. " 'Drawing a Better Line: Uti Possidetis and the Borders of New States'." American Journal of International Law 90: 590-624.

Rawls, John 1971. A Theory of Justice. Cambridge, Mass.: Harvard University Press

Requejo, Ferran, and Klaus-Jürgen Nagel. 2017. "Democracy and Borders:External and Internal Secession in the Eu." Euborders Working Paper.

Roeder, Philip G. 2007. Where Nation-States Comes From. Institutional Change in the Age of Nationalism. Princeton and Oxford: Princeton University Press.

Saward, Michael. 2010. Saward, M. 2010. The Representative Claim. Oxford: Oxford University Press.

Skoutaris, Nikos. 2017. "Territorial Differentiation in Eu Law: Can Scotland and Northern Ireland Remain in the Eu and/or the Single Market?". Cambridge Yearbook of European Legal Studies: 287-310.

Steiner, Hillel. 1998. "Territorial Justice." In Theories of Secession, ed. Percy Lehning. London and New York: Routledge: 60-70.

Stilz, Anna. 2015. "Decolonization and Self-Determination." Social Philosophy \& Policy 23: 1-24.

-_-. 2011. "Nations, States, and Territory." Ethics 121: 572-601.

Stjepanovic, D. and S. Tierny (2018). "The Right to Vote: Constitutive Referendums and Regional Citizenship?" Ethnopolitics, forthcoming.

Tamir, Yael. 1993. Liberal Nationalism. Princeton: Princeton University Press.

Tully, James. 2001. Introduction. In Multinational Democracies, eds. A.-G. Gagnon and J. Tully. Cambridge: Cambridge University Press: 1-33.

Walker, Neil. 2017. "Internal Enlargement in the European Union: Beyond Legalism and Political Expediency." In Secession from a Member State and Withdrawal from the European Union. Troubled Membership, ed. Carlos Closa. Cambridge: Cambridge University Press. 32-47.

Weinstock, Daniel. 2001. "Constitutionalizing the Right to Secede." The Journal of Political Philosophy 9: 182-203.

Wellman, Christopher H. . 1995. "A Defense of Secession and Political Self-Determination." Philosophy and Public Affairs 24: 142-71.

Wellman, Christopher Heath. 2005. A Theory of Secession. The Case for Political Self-Determination. Cambridge, UK: Cambridge University Press.

Ziegler, Ruvi, Jo Shaw, and Rainer Bauböck. 2014. "Independence Referendums: Who Should Vote and Who Should Be Offered Citizenship?", Eui Working Paper RSCAS 2014/90, Florence. 